\title{
Why Gulf of Mannar is a Marine Biological Paradise?
}

\author{
Jyothibabu R ${ }^{1}$, KK Balachandran ${ }^{1}$, L Jagadeesan ${ }^{1}$, C Karnan ${ }^{1}$, G.V.M Gupta ${ }^{2}$, K \\ Chakraborty $^{3}$, and K.C Sahu ${ }^{4}$ \\ ${ }^{1}$ National Institute of Oceanography CSIR \\ ${ }^{2}$ Centre for Marine Living Resources and Ecology Cochin \\ ${ }^{3}$ INCOIS \\ ${ }^{4}$ Berhampur University
}

July 8, 2020

\begin{abstract}
The Gulf of Mannar (GoM), located between India and Sri Lanka, has astonishing faunal richness and diversity1. Two oceanographic data sets are discussed here to show the unique ecological setting in the GoM sustaining a rich and diverse fauna. We tested the hypothesis that a specific stretch of a large marine environment behaves differently from the rest of the region due to its peculiar geographical positioning. Primarily, unlike the adjacent Indian southwestern shelf, coastal upwelling and the associated seasonal oxygen deficiency, potentially imparting physiological stress to marine fauna2-7, does not occur in the GoM. Secondly, the GoM along the Indian coastline receives adequate amount of primary (plankton) food from the Arabian Sea and the Bay of Bengal through the seasonally reversing coastal currents8-12. Thirdly, the GoM water has high transparency, aerated and sandy seafloor conducive for the growth of diverse corals and many sensitive fauna1,4. Our studies show that oxygen deficiency sheltered geography has a significant role in facilitating significantly high faunal diversity and richness in the GoM. We suggest that other similar coastal environments worldwide, protected from the extended oxygen-deficient region, might be functioning as a refuge for marine life and thereby increased faunal diversity 6,7 .
\end{abstract}

\section{Introduction}

The northern sector of the GoM is the first Indian Marine Biosphere Reserve ${ }^{1}$. The GoM, along its Indian coastline, has a spread of $\sim 1500 \mathrm{~km}^{2}$ that extends typically from Tuticorin to Mandapam ${ }^{8}$ over a distance of $\sim 190 \mathrm{~km}$ (Figure 1). The GoM has astonishingly rich and diverse fauna compared to the adjacent regions, and the 'Kurusadai' Island, one of the 21 small islands situated close to the Indian coastline in the GoM, is traditionally known as 'Marine Biologist's Paradise'. During 2010 - 2011, researchers from the National Institute of Oceanography, India including us have carried out oceanographic observations in the GoM and the adjacent Palk Bay (PB) as a feasibility study to link these water bodies through the Sethusamudram Ship Channel proposed by the Govt. of India. As an outcome of this, a series of peer-reviewed publications have come out dealing with their general environmental setting ${ }^{8-12}$. Even though a large number of studies are available on the faunal diversity in the GoM, convincing explanation on its oceanographic causes is completely absent ${ }^{1}$. Since the GoM is an extension of the Southeastern Arabian Sea (SEAS), differentiating the features of the GoM from the SEAS has great importance. The main objective of this paper is to establish the oceanographic and ecological reasons that facilitate an unusually rich and diverse fauna in the GoM. For which we examined here, the general characteristics of the $\mathrm{GoM}^{8-12}$ besides elaborating upon a crucial environmental signal found in our 2010-11 in-situ studies in the GoM. Also verified these results using a recent oceanographic survey in 2018 covering the southwest coast of India up to the western boundary of the GoM (Tuticorin) augmented with satellite remote sensing data sets and Regional Ocean Model System (ROMS) projections. 


\section{Materials and methods}

Online databases (http://giovanni.gsfc.nasa.gov, http://apdrc.soest.hawaii.edu) provided data on sea surface temperature (SST), surface winds, and chlorophyll-a. Ferret (version 7) was used for generating the monthly composite maps of these parameters. The first in-situ data from 2010 - 11was obtained from 15 locations in the GoM for three seasons [March 2010 (Pre-Monsoon), September 2010 (Southwest Monsoon), and January 2011 (Northeast Monsoon)]. Field sampling for this was conducted on board a trawler along five crossshore transects in the Indian sector of the GoM (GoM1 to GoM5) (Figure 1). The second in-situ sampling was in September (Southwest Monsoon) 2018 to verify whether the coastal upwelling process occurs in the GoM. This sampling was carried out onboard CRV Sagar Purvi with three sampling locations in each of the five cross-shore transects (SP1 to SP 5) from the western proximity of the GoM up to $12^{\circ} \mathrm{N}$ along the southwest coast of India (Figure 1). A portable Conductivity Temperature Depth (CTD) profiler (Seacat, Seabird Electronics, USA) recorded vertical distribution of temperature and salinity. Standard Winkler's method $^{13}$ was used to estimate the dissolved oxygen concentration from the surface, subsurface, and bottom waters in the first sampling during 2010-2011 and from many prefixed standard depths $(1 \mathrm{~m}, 5 \mathrm{~m}, 10 \mathrm{~m}$, $20 \mathrm{~m}$, and $40 \mathrm{~m}$ ) during the second sampling in 2018. We also used the Regional Ocean Model System (ROMS) outputs of the vertical distribution of relevant environmental variables for the Southwest Monsoon period, obtained from the Indian National Centre for Ocean Information Services (INCOIS), Hyderabad, India (www.incois.gov.in) ${ }^{14,15}$. Vertical sections of four cross-shore transects (T1-T4) obtained from ROMS beginning from the southern tip of India (Cape Comorin) towards the GoM were used to comprehend how best the model projection follows the environmental signatures evident in the in-situ observations ${ }^{14,15}$. Univariate ANOVA identified the significance of the spatial difference in hydrographical parameters between transects sampled in during 2018 (SP1-SP5). Before the ANOVA test, the homogeneity and distribution of the environmental variables were analysed using XL Stat PRO software. Tukey's HSD post hoc test was performed for pairwise data comparisons. The distribution of the ecological variables was analysed in XL stat Pro (License information - Academic version, Purchased by CSIR-National Institute of Oceanography, Regional centre, Kochi). ANOVA was analysed in PASTUiO software Version 4.02 (Free software downloaded from -https://folk.uio.no/ohammer/past/). Principle Component Analysis (PCA) was also performed to visualise the spatial differences in the distribution of relevant environmental variables. Correlation matrixbased scaling was used in PCA Biplots, having the first two principal components. The dissolved oxygen values were overlaid (dotted line) on the Biplots to indicate the spatial variation. PCA was performed using CANOCA 4.5 software purchased by the CSIR- National Institute of Oceanography, Regional centre, Kochi.

\section{Results and discussion}

\subsection{Environmental setting}

\subsubsection{Winds}

The surface winds in the study domain are weak during March-April (Pre-Monsoon) period (Supplementary Figure 1). Strong westerly/north-westerly winds $\left(>6 \mathrm{~m} \mathrm{~S}^{-1}\right)$ blows along the southwest coast of India from mid-May to September (Southwest Monsoon) due to the orographic influence of the western ghats ${ }^{16}$. Instead, well organised south-westerly winds blow over the GoM during the Southwest Monsoon. The wind speed enhances by May, peaks in June and remains steady till September. By October, winds weaken and by November change its direction to north-easterly, which peaks during December-January and then subsides by February. The surface wind in the GoM is always forceful than its adjacent regions. One most possible reason could be the wind tunnelling effect by the orography of the vast Western Ghats mountain ranges situated along the southwest coast of India and Knuckles mountain ranges in south-central Sri Lanka (Figure $1)$.

\subsubsection{SST}

Distribution of SST in the SEAS and the GoM has some characteristic behaviour (Supplementary Figure 2). The warmest SST in the study domain exists during the Pre-Monsoon, which is the first solar heating period in the region ${ }^{17,18}$. Following it, relatively cold water appears along the southwest coast of India and the GoM 
by June, and this cold SST situation prevails till October. It is also evident that much cooler SST $\left(25-26^{\circ} \mathrm{C}\right)$ prevails along the Southwest coast of India compared to the GoM $\left(\sim 27^{\circ} \mathrm{C}\right)$ during the Southwest Monsoon (May to September). Also, the cooler water patch persists for longer duration in the southern tip of the southwest coast of India as it lasts from May to October, probably a cause of extended periods of upwelling there by local winds ${ }^{16}$. The upwelling signatures appear first at the southern tip of Indian subcontinent ${ }^{1}$ and later advances northward along with the coastally trapped Kelvin wave ${ }^{19,20}$. Though the cold water along the southwest coast of India disappears by October, relatively cold water reappears in the GoM by November. It lasts up to February (Northeast Monsoon), as a continuity of the cold water mass in the Bay of Bengal, intruded through the Palk Bay ${ }^{21}$.

\subsubsection{Chlorophyll- $a$}

Pre-Monsoon (March-May) and Northeast Monsoon (November - February) are low productive periods in the SEAS along the southwest coast of India (Supplementary Figure 3). This situation is caused by surface layer stratification through solar heating during the Pre-Monsoon and the intrusion of low saline oceanic Bay of Bengal waters during the Northeast Monsoon ${ }^{22}$. Both these cause meagre nutrient availability in the upper euphotic column creating low phytoplankton biomass (chlorophyll-a) concentration ${ }^{22}$. The situation significantly changes by late-May/June as a result of coastal upwelling, and enhanced chlorophyll$a$ concentration starts appearing along the entire coastline by June and persists up to October. GoM has always moderate to the high level of chlorophyll- $a$ present in the nearshore waters along the Indian coast. Enhancement of chlorophyll- $a$ in the GoM starts by late-May, just after the Pre-Monsoon, and it peaks during July-August and then declines by September-October. During the Northeast Monsoon, though the chlorophyll- $a$ concentration decreases in the offshore waters in the GoM, its moderate concentration persists in the shelf waters along the Indian coastline as a continuity of the water masses intruded from the Bay of Bengal through the Palk Bay.

\subsubsection{The contrast of GoM from the southwestern shelf of India}

The environmental variables collected during the first in-situ sampling during 2010-2011 (Table 1) shows that the hydrography of the GoM was very similar to the waters in the SEAS along the southwest coast of India $^{8-12}$. At the same time, the vertical distribution of temperature and dissolved oxygen in the GoM during the Southwest Monsoon displayed two significant features, which were strikingly different from the southwest coast of India during the same period. The water column in the GoM during the Southwest Monsoon was warm $\left(>26^{\circ} \mathrm{C}\right)$ and without any significant vertical temperature gradients (Figure 2), unlike that on the southwest coast of India due to coastal upwelling. Also found in this data high oxygen concentration throughout the water column $\left(>4.2 \mathrm{mg} \mathrm{L}^{-1}\right.$ ) negating the possibility of coastal upwelling in the GoM (Figure 3 ). We confirmed the robustness of this feature based on a few earlier records on the environmental variables from this region ${ }^{23,24}$. The upwelling along the southwest coast of India during the Southwest Monsoon ${ }^{16,25,26}$ and its implications on the biological resources are well known ${ }^{2,3,27-30}$. During the Southwest Monsoon, westerly/north-westerly winds close to the coastline induces upwelling along the west coast of India ${ }^{16,26,27}$, which lowers the SST by $4-5^{\circ} \mathrm{C}^{2,27}$. During this process, the cold $\left(23^{\circ} \mathrm{C}\right)$ and low oxygenated $\left(\sim 2 \mathrm{mg} \mathrm{L}{ }^{-1}\right)$ deep oceanic waters (from $75-150 \mathrm{~m}$ ) are elevated to the surface waters along the entire west coast of India ${ }^{2,27-30}$. Both local winds and remote forcing facilitate coastal upwelling along the extensive southwest coast of India ${ }^{18,26-30}$.

The vertical distribution of temperature and dissolved oxygen at different depth zones $(10 \mathrm{~m}, 25 \mathrm{~m}$, and $40 \mathrm{~m})$ in the shelf waters along the southwest coast of India up to the western proximity of the GoM (Tuticorin) clearly shows coastal upwelling signatures in terms of the surfacing of cold and low-oxygenated deep water (Figure 4). The most striking feature here in the present context is the spatial extent of the cold and low oxygenated water in the three depth zones. Along with the $10 \mathrm{~m}$ depth, upwelling signatures were evident up to Vizhinjum (SP2), but in $25 \mathrm{~m}$ and $40 \mathrm{~m}$, it was apparent up to Kulasekharapatnam (SP4). ANOVA results confirmed the significant spatial differences in the levels of temperature and dissolved oxygen between the northern (SP1 \& $\mathrm{SP} 2)$ and southern (SP4 \& SP5) sections $(\mathrm{P}<0.05$; Supplementary Table 1). PCA showed that transects in the western proximity of the GoM (SP4 and SP5) were significantly warmer and more oxygenated compared 
to those in the north along the southwest coast of India (SP1 and SP2) (Supplementary Figure 4). All the in-situ data showed that upwelling along the Indian southwest coast does not extend towards the GoM. This feature is also consistent in the vertical sections of temperature and dissolved oxygen in ROMS, showing that the coastal upwelling prevails only up to the southern Indian tip (Cape Comorin) and does not extend into the GoM (Supplementary Figure 5). This vital feature we reaffirmed in a historical oceanographic survey data sets published, as the upwelling signatures of the southwest coast of India phase-out by reaching the western proximity of the GoM (Tuticorin) region ${ }^{31}$ (Supplementary Figure $6 \& 7$ ). The reason for the absence of coastal upwelling in the GoM could be the alignment of its coastline differently from the Indian southwest coastline. Thus, the wind and remote forces, which cause upwelling along the adjacent southwest coast of India might not be favouring upwelling in the GoM as observed in the case of the western and eastern shores of Sri Lanka ${ }^{32}$.

\subsubsection{Why the GoM is a marine biological paradise?}

The Indian Continental shelf of GoM is significantly narrow $(<20 \mathrm{~km} \text { cross-shore expand })^{1,8}$. Being a tropical region, the GoM has a warm climate with less change in sea surface temperature over seasons $\left(26.5 \text { to } 30.3^{\circ} \mathrm{C}\right)^{8}$. The sea surface salinity in the GoM varies seasonally $(32-35.4)$, but remains high due to its continuity to the Arabian Sea and the lack of any significant rivers in the vicinity ${ }^{8,11}$. The GoM gets partially renewed during the Southwest Monsoon (May - September) associated with the large scale ocean circulation around India and Sri Lanka ${ }^{8,9,11}$. The surface currents in the GoM during the Southwest Monsoon (May to September) enables the flow of high saline Arabian Sea waters into the PB. The surface currents reverse during the Northeast Monsoon (November - February) and bring the coastal low saline Bay of Bengal waters into the GoM (Table 1). This circulation pattern enables (a) GoM to receive a high amount of plankton stock from the Arabian Sea during the Southwest Monsoon and from the Bay of Bengal during the Northeast Monsoon ${ }^{8,10,11}$ and, (b) Palk Bay to efficiently trap the suspended sediments coming from the Bay of Bengal during the Northeast Monsoon ${ }^{10,11}$. As a result, the bottom sediment in the GoM is mostly sandy and well-aerated conducive for the life of diverse corals and sensitive fauna ${ }^{1,4}$.

The nearshore characteristics of the Indian southwestern shelf and the GoM evidenced the oceanographic mechanisms that make the GoM evolve into a biological resource reserve. Primarily, during the Southwest Monsoon, the entire western shelf waters of India are under the influence of the coastal upwelling and the incursion of the oxygen-deficient waters ${ }^{27-29}$. This situation has a profound influence on organisms living in the nearshore region along the southwest coast of India ${ }^{2-4,28,29,33}$. In contrast, the adjacent GoM is devoid of any such negative impacts of low oxygenated waters on fauna. The benthic habitats in the shelf waters are the feeding grounds for most of the demersal finfishes and shellfishes and provide a link between the water column and fisheries ${ }^{2,33-36}$. Mobile consumers of benthic macro-invertebrates usually emigrate/escape from areas where dissolved oxygen concentrations reach hypoxic levels ${ }^{2,33-37}$. Demersal finfishes and shellfishes disappear seasonally from the outer shelf of the southwest coast of India and often aggregate in oxygenated estuarine waters $^{2,29,38}$. If low-oxygen conditions are relatively mild, some of these demersal consumers may remain in the vicinity for a short period, exploiting stunned benthic prey, which is not customarily available ${ }^{39-41}$. As dissolved oxygen concentrations rise after the hypoxic event, mobile demersal consumers generally return to their original habitat. While higher consumers may benefit from easy access to stressed prey in some areas, the large spatial and temporal extent of seasonal hypoxia is likely to limit higher trophic - level transfer via the inhibition of macrobenthic production ${ }^{42,43}$.

Oxygen deficiency is the primary cause of the dead zones in the world ocean ${ }^{41-44}$. Dissolved oxygen is the prime physiological driver of respiration, photosynthesis, and calcification of coral communities ${ }^{44,45}$. Crustaceans and echinoderms are typically more sensitive to hypoxia, and at $<2 \mathrm{mg} \mathrm{L}^{-1}$ dissolved oxygen, crustacean dies within $119 \mathrm{~h}$ of exposure, is the reason for piles of dead crabs or lobsters a common feature in hypoxic zones ${ }^{34-41}$. Naturally, the lack of seasonal hypoxia in the GoM avoids the seasonal wipe out of sensitive fauna there, facilitating increased faunal richness and diversifications, which is advantageous especially to the native sessile and sedentary organisms having longer life span. Sedentary organisms like molluscs, echinoderms and clams may undertake seasonal migration from the Indian southwestern shelf to 
the GoM as a response to escape from low oxygenation during the Southwest Monsoon ${ }^{2,4}$. So here we propose that the hypoxia avoidance migration of the mobile fauna from the nearby southwestern Indian shelf may also be contributing to the precious resource potential of arthropods, molluscs, bivalves and echinoderms inhabiting in the $\mathrm{GoM}^{1}$. Thus GoM may also be acting as a refuge for marine fauna while oxygen-deficient waters spread over the Indian southwestern shelf (Supplementary Figure 8). Availability of primary (plankton) food is another essential requirement in sustaining a rich and diverse fauna in any aquatic ecosystem. In the GoM, this gets possible chiefly through the seasonal surface circulation along the Indian shelf waters. The GoM receives the positive effect of upwelling (as plankton-rich advected surface waters) during the Southwest Monsoon from the southwest coast of India. Relatively low saline (planktonrich) coastal waters from the Bay of Bengal complement the plankton availability in the GoM during the Northeast Monsoon. Thus the adequate amount of plankton stock (primary food) occurs in the GoM almost throughout the year. All these positive factors facilitate an advantageous ecological setting in the GoM with very minimal seasonal variations in major environmental parameters (temperature, salinity, dissolved oxygen, and plankton stock). This situation helps to sustain high species diversity (k-selection) and build up their population sizes to the maximum of the carrying capacity of the environment. We revealed the GoM as a naturally evolved invaluable resource reserve in the region, especially during the upwelling time (Southwest Monsoon) when seasonal wipe out of sensitive fauna occurs along the southwestern Indian shelf. Indeed, the sheltered geographical positioning between India and Sri Lanka made the GoM a naturally gifted faunal resource reserve in the region.

\section{Acknowledgements}

The authors thank the Directors of the CSIR-National Institute of Oceanography (Dr Satish R Shetye, Dr S.W.A. Naqvi, and Prof. Sunil Kumar Singh) for the facility and encouragement. Part of the sampling for this study in connection with the Marine Ecosystem Dynamics of the Eastern Arabian Sea (MEDAS) was funded by the Ministry of Earth Sciences (MoES) through National Centre for Coastal Research (NCCR), Chennai. India. We thank Dr M. Sudhakar, the former Director, Centre for Marine Living Resources and Ecology (CMLRE), Kochi, and Dr M.V. Ramanamurty, Director, NCCR, Chennai for their wholehearted support to the MEDAS program. We thank all the field participants in the GoM during 2010-2011 and also along the Southwest coast of India in 2018. The authors thank Mr Rajasekhar and Mr Sundar, vessel Management Cell, National Institute of Ocean Technology (NIOT), Chennai, as well as the Captain and crew of ORV Sagar Purvi cruise in September 2018 to complete the field measurements under a hostile sea environment.

\section{References}

1. Subba Rao, D. V., Srinivasa Rao, K., Iyer, C. S. P., Chittibabu, P., 2008. Possible ecological consequences from the Sethu Samudram canal project India. Marine Pollution Bulletin 56, 172-186.

2. Banse, K., 1959. On the upwelling and bottom trawling off the southwest coast of India. J. Mar. Biol. Ass. of India, 1, 33-49.

3. Banse, K., 1968. Hydrography of the Arabian Sea shelf of India and Pakistan and effects on demersal fishes. Deep-Sea Res. I, 15, 45-79.

4. Parameswaran, U. V., Jaleel, A.K.U., V.N. Sanjeevan, V.N., Gopal, A., Sudhakar, M., 2018. Diversity and distribution of echinoderms in the South Eastern Arabian Sea shelf under the influence of seasonal hypoxia. Progress in Oceanography 165:189-204.

5. Jagadeesan, L., Jyothibabu, R., Arunpandi, N., Karnan, C., Balachandran, K.K., 2017. Dominance of coastal upwelling over Mud Bank in shaping the mesozooplankton along the southwest coast of India during the Southwest Monsoon. Progress in Oceanography, 156, 252-275.

6. De Leo, F.C., Pires-Vanin, A. M. S., 2006. Benthic megafauna communities under the influence of the South Atlantic Central Water intrusion onto the Brazilian SE shelf: A comparison between an upwelling and a non-upwelling ecosystem. Journal of Marine Systems 60, 268-284.

7. Rodrigues, C.W., Pires-Vanin, A.M.S., 2012. Spatio-temporal and functional structure of the amphipod communities off Santos, Southwestern Atlantic. Brazilian Journal of Oceanography 60, 421-439. 
http://dx.doi.org/10.1590/S1679-87592012000300013.

8. Jagadeesan, L., Jyothibabu, R., Anjusha, A., Mohan, A.P., Madhu, N.V., Muraleedharan, K.R., Sudheesh, K., 2013. Ocean currents structuring the mesozooplankton in the Gulf of Mannar and the Palk Bay, southeast coast of India. Progress in Oceanography 110, 27-48.

9. Amrutha M. M., Sanil Kumar, V., 2017. Observation on the dominance of swells over windseas in the coastal waters of Gulf of Mannar, India. Journal Ocean Science Discussion papers. https://doi.org/10.5194/os-2017-16.

10. Jyothibabu, R., Madhu, N.V., Jagadeesan, L., Anjusha, A., Mohan, A.P., Ullas, N., Sudheesh, K., Karnan, C., 2014. Why do satellite imageries show exceptionally high chlorophyll in the Gulf of Mannar and the Palk Bay during the Northeast Monsoon? Environmental Monitoring and Assessment 186, 7781-7792.

11. Anjusha, A., Jyothibabu, R., Jagadeesan, L., Mohan, A.P., Sudheesh, K., Krishna, K., Ullas, N., Deepak, M.P., 2013. Trophic efficiency of plankton food webs, Observations from the Gulf of Mannar and the Palk Bay, Southeast Coast of India. Journal of Marine Systems 115 -116, 40-61.

12. Madhu, N.V., Ullas, N., Ashwini, R., Meenu, P., Rehitha, T.V., Lallu, K.R., 2014. Charecterization of phytoplankton pigments and functional community structure in the Gulf of Mannar and Palk Bay using HPLC-CHEMTAX analysis. Continental Shelf Research, 80, 79-90.

13. Grasshoff, K., 1983. Methods of Seawater Analysis. In K. Grasshoff, Ehrhardt, M., Kremling, K., (Ed.) Weinheim, Verlag Chemie, pp. 419.

14. Chakraborty, K., Guptab, A., Lotliker, A. A., Tilstonec, G., 2016. Evaluation of model-simulated and MODIS-Aqua retrieved sea surface chlorophyll in the eastern Arabian Sea. Estuarine, Coastal and Shelf Science 181, Pages 61-69.

15. Chakraborty, K., K. Valsala, V., Gupta, G. V. M., and Sarma, V. V. S. S. 2018. Dominant biological control over upwelling on pCO2 in sea east of Sri Lanka. Journal of Geophysical Research: Biogeosciences. https://doi.org/10.1029/2018JG004446.

16. Harish Kumar, P. V. and Anand, P., 2016. Coastal upwelling of the southwest coast of India: Observations and simulations, International Journal of Digital Earth 9, 12562, 1274.

17. Shenoi, S. C., Shankar, D., Gopalakrishna, V. V., Durand. F., 2005. Role of the ocean in the genesis and annihilation of the core of the warm pool in the Southeastern Arabian Sea. Mausam 56, 147-160.

18. Kurian, J., Vinayachandran P. N., 2007. Mechanisms of formation of the Arabian Sea mini warm pool in a high-resolution Ocean General Circulation Model. Journal of Geophysical Research112, C05009, DOI:10.1029/2006JC003631, 200.

19. McCreary, J. P., P. K. Kundu, and R. L. Molinari. 1993. "A Numerical Investigation of Dynamics, Thermodynamics and Mixed-layer Processes in the Indian Ocean." Progress in Oceanography 31 (3): $181-244$.

20. Shankar, D., and S. Shetye. 1997. "On the Dynamics of the Lakshadweep High and Low in the Southeastern Arabian Sea." Journal of Geophysical Research 102: 12551-12562.

21. Rao, R.R., Gireeshkumar, M.S., Ravichandran, M., Gopalakrishna, V.V., Thadathil, P., 2011. Do cold low saline waters pass through the Indo Sri Lankan channel during winter? International Journal of Remote Sensing 327383-7398.

22. Jyothibabu, R., Madhu, N.V., Habeebrehman, H., Jayalakshmy, K.V., Nair, K.K.C., Achuthankutty, C.T., 2010. Re-evaluation of 'paradox of mesozooplankton' in the eastern Arabian Sea based on ship and satellite observations. Journal of Marine Systems 81, 235-251.

23. Jayaraman, R., 1954. Seasonal variations in salinity, dissolved oxygen and nutrient salts in the inshore waters of the Gulf of Mannar and Palk Bay near Mandapam (S. India). Indian Journal of Fisheries, 1 (1\&2). Pp. 345-364.

24. Bindu, S., Muniyandi, K., 2005. Hydrographic parameters off the Gulf of Mannar and Palk Bay during an year of abnormal rainfall. Journal of Marine Biological Association of India 47 (2): 198-200.

25. Ramasastry, A.A., Myrland, P., 1959. Distribution of temperature, salinity and density in the Arabian Sea along the South Malabar Coast (South India) during the post-monsoon season. Indian Journal of Fisheries 6, 223-255. 
26. Shetye, S.R., Gouveia, A.D., Shenoi, S.S.C., 1994. Circulation and water masses of the Arabian Sea. Proc. Indian Acad. Sci. Earth Planet. Sci. 103, 107-123.

27. Naqvi, S.W.A., Naik, H., Jayakumar, D.A., Shailaja, M.S., Narvekar, P.V., 2006. Seasonal Oxygen deficiency over the western continental shelf of India Past and Present Water Column Anoxia, Vol. 64 Springer Netherlands, 195-224.

28. Gupta, G. V. M., Sudheesh, V., Sudharma, K. V., Saravanane, N., Dhanya, V., Dhanya, K. R., Lakshmi, G., Sudhakar, M., Naqvi, S. W. A., 2016. Evolution to decay of upwelling and associated biogeochemistry over the southeastern Arabian Sea shelf. Journal of Geophysical Research, Bio geosciences 121,159-175.

29. Karnan, C., Jyothibabu, R., Arunpandi, N., Jagadeesan, L., Muraleedharan, K.R., Pratihari, A.K., Balachandran, K.K., Naqvi, S.W.A., 2017. Discriminating the biophysical impacts of coastal upwelling and mud banks along the southwest coast of India. Journal of Marine Systems, 172, 24-42.

30. Jyothibabu, R., Balachandran, K.K., Jagadeesan, L., Karnan, C., Arunpandi, N., Naqvi, S.W.A., Pandiyarajan, R.S., 2018. Mud Banks along the Southwest Coast of India are not too muddy for plankton. Scientific Reports 8(1), 2544.

31. Johannessen, O.M., Subaraju, G., Blindheim, J., 1981. Seasonal variations of the oceanographic conditions off the Southwest coast of India during 1971 - 1975. FiskDir.SKR.Ser.HavUnders18, 247261.

32. Vinayachandran, P.N., Chauhan, P., Mohan, M., Nayak, S., 2004. Biological responses of the seas around Sri Lanka to summer Monsoon. Geophysical Research Letters 31, L01302.

33. Regunathan, A., Mathew, K.J., Kurup, N.S., Murty, A.V.S., 1981. Monsoon fishery and Mud Banks of Kerala coast. Bulletin of the Central Marine Fisheries Research Institute 30, 37- 41.

34. Pihl, L., Baden, S.P., Diaz, R.J., 1991. Effects of periodic hypoxia on distribution of demersal fish and crustaceans. Marine Biology, 108, 349-360.

35. Rabalais, N.N., Harper, D.E Jr.., Turner, R.E., 2001. Responses of nekton and demersal and benthic fauna to decreasing oxygen concentrations. In: Rabalais NN, Turner RE (eds.) Coastal hypoxia: consequences for living resources. Coastal and Estuarine Studies,58. American Geophysical Union, Washington, DC, 115-128.

36. Pihl, L., Baden, S.P., Diaz, R.J, Schaffner, L.C., 1992. Hypoxia-induced structural changes in the diet of bottom-feeding fish and crustacea. Marine Biology, 112, 349-361.

37. Pihl, L., 1994. Changes in the diet of demersal fish due to eutrophication-induced hypoxia in the Kattegat, Sweden. Canadian Journal of Fisheries Aquatic Sciences, 51, 321-336.

38. Seitz, R.D., Marshall, L.S., Hines, A.H., Clark, K.L., 2003. Effects of hypoxia on predator-prey dynamics of the blue crab Callinectes sapidus and the Baltic clam Macoma balthica in Chesapeake Bay. Marine Ecology Progress Series, 257,179-188.

39. Santos, S.L., Simon, J.L., 1980. Marine soft-bottom community establishment following annual defaunation: larval or adult recruitment? Marine Ecology Progress Series, 2, 235-241.

40. Powers, S.P., Harper, D.E Jr., Rabalais, N.N., 2001. The effect of large scale hypoxia/anoxia on the supply and settlement of benthic invertebrate larvae. In: Rabalais N.N, Turner R.E (eds.) Coastal hypoxia: consequences for living resources. Coastal and Estuarine Studies 58. American Geophysical Union, Washington, DC, 165-184.

41. Diaz, R.J., Rosenberg, R., 2008. Spreading Dead Zones and Consequences for Marine Ecosystems. Science, 321, 926-929.

42. Officer, C. B., Briggs, R. B., Taft, J. L., Cronin, L, E., Tyler, M. A., Boyton, W. R. 1984. Chesapeake Bay anoxia. Origin development and significance. Science, N. Y. 223-227.

43. Chan, M., Barth, J.A., Lubechenco, J., Kirincich, A., Weeks, H., Pterson, W.T., Menge, B.A., 2008. Emergence of anoxia in the California Current Large Marine Ecosystems, Science 319, 920.

44. Altieri, A.H., Harrison, S.B., Seemaan, J., Collin, R., Diaz, R.J., Knowlton, N., 2017. Tropical dead zones and mass mortalities on coral reefs. PNAS 114, 3665.

45. Nelson, H.R., Alteir, A.H., 2019. Oxygen: the universal currency on coral reefs. Coral Reefs, 2019.

Table 1 - Salient seasonal environmental characteristics of the GoM. Abbreviations: GoM - Gulf of Mannar, 
SWM - Southwest Monsoon, NEM - Northeast Monsoon, SEAS - Southeastern Arabian Sea

Variables

Surface currents

Wind, Sea surface temperature, Sea surface salinity

Waves

Turbidity

Nitrate and Dissolved oxygen

Chlorophyll $a$

Zooplankton

\section{Salient features of the GoM}

Water flow in the GoM is in conjunction with the large scale circulati Strong winds prevail in the GoM during the SWM, followed by the N The waves are lower in the GoM as compared to the SEAS ${ }^{9}$. Swells $c$ Clear waters occur in the GoM throughout the year, while Palk Bay Moderate to the high concentration of nitrate during SWM and NEN Moderate $\left(0.4 \mathrm{mg} \mathrm{m}^{3}\right)$ to high $\left(1.8 \mathrm{mg} \mathrm{m}^{3}\right)$ level of phytoplankton stc GoM has high zooplankton stock during the SWM and NEM periods

\section{Hosted file}

Figure 1 - Study Area and Sampling Locations.docx available at https://authorea.com/users/ 340812/articles/467874-why-gulf-of-mannar-is-a-marine-biological-paradise

\section{Hosted file}

Figure 2 - Vertical Temperature in the GoM (2).docx available at https://authorea.com/users/ 340812/articles/467874-why-gulf-of-mannar-is-a-marine-biological-paradise

\section{Hosted file}

Figure 3 - Vertical Dissolved Oxygen in the GoM.docx available at https://authorea.com/users/ 340812/articles/467874-why-gulf-of-mannar-is-a-marine-biological-paradise

\section{Hosted file}

Figure 4 - Vertical Distribution of Temp. and DO SW coast.docx available at https: //authorea.com/users/340812/articles/467874-why-gulf-of-mannar-is-a-marine-biologicalparadise 